IRA-International Journal of Education \& Multidisciplinary Studies

ISSN 2455-2526; Vol.03, Issue 03 (2016)

Institute of Research Advances

http://research-advances.org/index.php/IJEMS

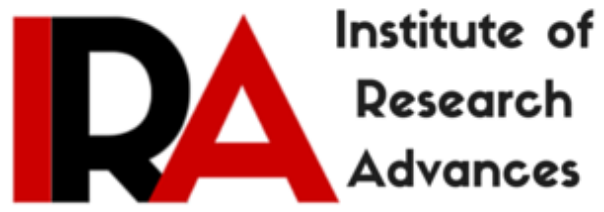

\title{
Palatability and Sensory Perception of Soursop (Annona Muricata) Tart Filling With Jute (Corchorus Olitorious) Leaves
}

\author{
${ }^{1}$ Delia C. Eusala \\ West Visayas State University-Janiuay Campus \\ Cabesa Jose D. Brana Street \\ Janiuay, Iloilo, Philippines.

\section{${ }^{2}$ Guiller P. Pendon} \\ West Visayas State University-Janiuay Campus \\ Cabesa Jose D. Brana Street \\ Janiuay, Iloilo, Philippines.
}

DOI: http://dx.doi.org/10.21013/jems.v3.n3.p15

\section{How to cite this paper:}

C. Eusala, D., \& P. Pendon, G. (2016). Palatability and Sensory Perception of Soursop (Annona Muricata) Tart Filling With Jute (Corchorus Olitorious) Leaves. IRA International Journal of Education and Multidisciplinary Studies (ISSN 2455-2526), 3(3).

doi:http://dx.doi.org/10.21013/jems.v3.n3.p15

\section{(C) Institute of Research Advances}

\section{(cc) BY-No}

This works is licensed under a Creative Commons Attribution-Non Commercial 4.0 International License subject to proper citation to the publication source of the work.

Disclaimer: The scholarly papers as reviewed and published by the Institute of Research Advances (IRA) are the views and opinions of their respective authors and are not the views or opinions of the IRA. The IRA disclaims of any harm or loss caused due to the published content to any party. 


\begin{abstract}
Seeing on the light that millions of the world's population were at risk of important nutrients, thus, this experimental study was made to consider the important nutrients through food fortification of soursop as tart filling and being enriched with jute leaves. There were three (3) treatments done in this study and these were $(5 \mathrm{~g}, 10 \mathrm{~g}$ and $15 \mathrm{~g}$ of jute leaves) on soursop tart filling. Respondents of the study who served as evaluators were the 60 BSHRST students who were randomly selected and 12 core teachers teaching in the School of Hotel and Restaurant Services Technology. The product was evaluated in terms of appearance, aroma, taste, texture and general acceptability. Utilizing the above criteria the result between students and teachers seems to vary. It vividly proved that students preferred treatment $B(10 \mathrm{~g})$ while teachers preferred treatment $A(5 g)$. Based on the findings, the conclusions and recommendations have been drawn to address the research gaps in the study.
\end{abstract}

Keywords: annona muricata, cochorus olitorius, jute, soursop, tart filling.

Many ordinary people might have tasted soursop as a raw fruit however to develop a soursop tart filling with jute leaves is not yet present in the food market. To some, the heart-shaped green spiky exterior of the fruit may probably do not look appetizing but when you eat it, it is luscious creamy white flesh, the taste buds will feast on the delicious combination of strawberry and pineapple with sour citrus notes contrasting with an underlying rich flavor reminiscent of coconut or banana. Extracts of soursop have been used for several medicinal purposes such as the management of diabetes and its complications, also as an antioxidant and anti-mutagenic agents (Al-Amoudi, 2012).

Many people today have no fitting appetite to jute leaves due to its physical texture and taste. Because jute plant is by nature a vegetable, it is easy to prepare and can be incorporated to various dishes that would allow individuals to benefit from its vitamins and mineral content. Jute is also known as saluyot or tugabang, is a green leafy vegetable that is rich in calcium, phosphorus, iron and potassium. It has also been determined that 100 grams of jute contains an ample amount of Vitamin A, thiamine, riboflavin, ascorbic acid, and is also rich in fiber source. With these facts alone, people can appreciate the benefits that can be derived from eating and incorporating saluyot in one's diet (Bender, 2005).

Our country is blessed with abundant resources like soursop and jute leaves. Its availability, sufficiency and high nutritional value of these crops, the researcher is encourage to use soursop and jute leaves as ingredients in making tart filling. Tarts are popular snack item or dessert among children and adult due to its delicious. Filling maybe fresh fruits, or chopped and sweetened jams or jellies. Tarts served as giveaways and finger food for family meals or for special occasions like birthdays and anniversaries, and other special occasions. This maybe packed in a colored cellophane to become more attractive to customers when served as dessert (Dadivas, 2008).

Based on DepEd Order No. 8, Series of 2007, or the Revised Implementing Guidelines on the Operation and Management of School Canteens in Public Elementary and Secondary Schools, only nutrientrich foods and fortified food products labeled rich in protein, energy, vitamins, and minerals shall be sold in school canteens.

According to DepEd Assistant Secretary Jesus Mateo, the DepEd is against selling of unhealthy food to students, especially in school canteens. There is an existing policy against selling of unhealthy food like junk food and other snacks as well as softdrinks inside the schools to make sure that pupils only eat nutritious foods when they are inside the school premises.

It has been observed that many young children and adults don't like to eat soursop and jute leaves as raw or as plain vegetables served as viand, however, if these two raw materials are being utilized as tart

Funded by: West Visayas State University-Janiuay Campus 
filling it may even help solve the micronutrient deficiency in the country and will improve the country's economy in terms of product development, job opportunities, and extra income for other, thus, this study was conducted.

This study aimed to determine the level of acceptability of soursop (Annona muricata) tart filling with $5 \mathrm{~g}$, $10 \mathrm{~g}, 15 \mathrm{~g}$ fresh jute (Corchurus Olitorious) leaves.

Specifically, this study sought to answer the following questions:

1. What is the level of acceptability of the soursop tart filling enriched with $(5 \mathrm{~g}, 10 \mathrm{~g}, 15 \mathrm{~g})$ fresh jute leaves when evaluated in terms of appearance, aroma, taste, texture and general acceptability.

2. Is there a significant difference in the level of acceptability of the soursop tart filling enriched with $5 \mathrm{~g}, 10 \mathrm{~g}, 15 \mathrm{~g}$ fresh jute leaves when evaluated in terms of appearance, aroma, taste, texture and general acceptability.

Methodology

This study determined the level of acceptability level of acceptability of the soursop tart filling enriched with $(5 \mathrm{~g}, 10 \mathrm{~g}, 15 \mathrm{~g})$ fresh jute leaves when evaluated in terms of appearance, aroma, taste, texture and general acceptability.

Biton (2009) stated that in experimental research there is at least one or more independent variables are deliberately manipulated to produce an effect and is considered the most sophisticated method for testing hypothesis involving cause-effect relationship. In this study, the randomized complete block design will be used which will be created in two stages.

The first stage consisted in grouping the observational units according to one or more factors. It required the number units in each group to be equal to the number of treatments. The number of groups should be equal to the number of replications.

The second phase was assigning the units in each group to treatment groups at random. A modification of this design should be the number of units in each group that is larger than the number of treatments (preferably, a multiple). The units in each group can be divided in subgroups. Each subgroup was assigned to a treatment group as a whole. In this study a fishbowl method was utilized, where there were three treatments added with jute leaves as filling and replicated three times.

\section{Lay - out of the experiment}

Below was the experimental lay-out that showed the treatment or recipes and the replications. There were three (3) treatments that were replicated 3 times.
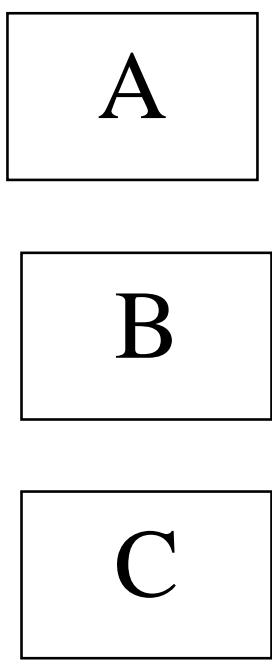
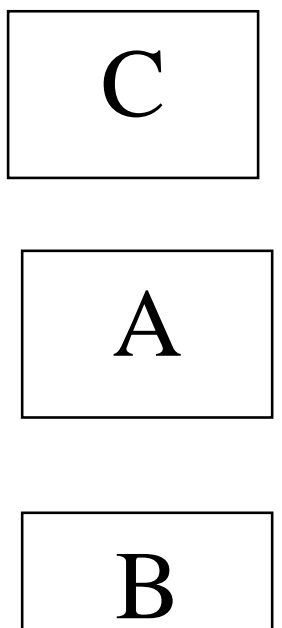
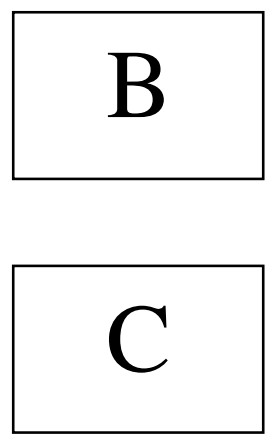

A 
Figure 2: Experimental Lay-out of the Study

Legend:

$\mathrm{A}=$ soursop tart filling with $5 \mathrm{~g}$ fresh jute leaves

$\mathrm{B}=$ soursop tart filling with $10 \mathrm{~g}$ fresh jute leaves

$\mathrm{C}=$ soursop tart filling with $15 \mathrm{~g}$ fresh jute leaves

\section{Sources of Data}

The source of data was the response of the evaluators was composed of 60 Bachelor of Hotel and Restaurant Services Technology students. They were purposively selected as evaluators of the finished product based on their expertise.

The HRST core faculty was chosen total enumeration. They were purposively chosen based on their knowledge and expertise in food preparation and access to the students in the dissemination of new discovery and the students' knowledge and skills in experimental cookery.

The evaluation scoresheet based on the five-point Hedonic Scale (Gatchalian, 1989) was modified by the researcher. The treatment was evaluated based on the following responses (5) extremely liked, (4) very much liked, (3) moderately liked, (2) very much disliked, and (1) extremely disliked.

Score was assigned in evaluating the product as to appearance, aroma, taste, texture and general acceptability.

\begin{tabular}{|l|l|l|l|}
\hline Ingredients & Treatment A & Treatment B & Treatment C \\
\hline Soursop & $1 \mathrm{C}$ & $1 \mathrm{C}$ & $1 \mathrm{C}$ \\
\hline Jute leaves & $5 \mathrm{~g}$ & $10 \mathrm{~g}$ & $15 \mathrm{~g}$ \\
\hline Sugar & $3 / 4 \mathrm{C}$ & $3 / 4 \mathrm{C}$ & $3 / 4 \mathrm{C}$ \\
\hline
\end{tabular}

Procedure

1. Wash jute leaves and drained until water was removed

2. Chopped the fresh jute finely. Set aside.

3. Wash ripe soursop fruit and then slice

4. Peeled and removed the seeds. Set aside.

5. Measure all ingredients and perform mis-en-place.

6. Combine all ingredients except jute leaves and cook in a sauce pan.

7. Stir constantly with a wooden spoon until thick to be spread out when lifted from the pan.

8. Put jute leaves and stir until well combined.

9. Remove from fire and let it cool.

10. Fill the tart shell.

11. Cool and serve

\section{Data Gathering Procedure}

The researcher secured permit from the office of the campus administrator to conduct the study to respondents in order to evaluate the soursop tart with jute leaves.

The researcher explained the criteria and the conduct of evaluation to the respondents. Total enumeration was done in choosing the faculty respondents.

The experiment started by dividing its activities into four phases: the preparation of materials and utensils, try out of the recipes, standardization of recipe and the evaluation of the soursop tart filling with jute leaves by the panel of evaluators. 
Phase 1

Preparation of tools and utensils needed

Measuring cup, mixing bowl, rubber scraper, wooden spoon, blender, utility bowl, knife and tart molder.

Phase 2- Try out of recipe

The following proportions and steps were followed in trying out of the recipes.

\begin{tabular}{|l|l|l|l|}
\hline Ingredients & Treatment A & Treatment B & Treatment C \\
\hline Soursop & $1 \mathrm{C}$ & $1 \mathrm{C}$ & $1 \mathrm{C}$ \\
\hline Jute leaves & $5 \mathrm{~g}$ & $10 \mathrm{~g}$ & $15 \mathrm{~g}$ \\
\hline Sugar & $1 \mathrm{C}$ & $1 \mathrm{C}$ & $1 \mathrm{C}$ \\
\hline
\end{tabular}

Procedure

12. Wash jute leaves and drained until water was removed

13. Chopped the fresh jute finely. Set aside.

14. Wash ripe soursop fruit and then slice

15. Peeled and removed the seeds. Set aside.

16. Measure all ingredients and perform mis-en-place.

17. Combine all ingredients except jute leaves and cook in a sauce pan.

18. Stir constantly with a wooden spoon until thick to be spread out when lifted from the pan.

19. Put jute leaves and stir until well combined.

20. Remove from fire and let it cool.

21. Fill the tart shell.

22. Cool and serve

Phase 3- Standardized recipe

After try-out and re-testing of soursop tart with jute leaves filling, the comments and suggestions from the panel of evaluators were considered for the improvement of the product and standardization of the final recipe.

Suggestions will be keenly followed and applied in the recipe.

\begin{tabular}{|l|l|l|l|}
\hline Ingredients & Treatment A & Treatment B & Treatment C \\
\hline Soursop & $1 \mathrm{C}$ & $1 \mathrm{C}$ & $1 \mathrm{C}$ \\
\hline Jute leaves & $5 \mathrm{~g}$ & $10 \mathrm{~g}$ & $15 \mathrm{~g}$ \\
\hline Sugar & $3 / 4 \mathrm{c}$ & $3 / 4 \mathrm{c}$ & $3 / 4 \mathrm{c}$ \\
\hline
\end{tabular}

Phase 4- Evaluation of soursop tart with jute leaves

After formulated the soursop tart with jute leaves and standardized, the final product will be prepared for final evaluation.

The product was evaluated by 60 Bachelor of Hotel and Restaurant Services Technology students and by the total enumeration of HRST core faculty in terms appearance, aroma, taste, texture, general acceptability.

The panel of evaluators were invited and given instructions on how to evaluate the soursop tart with jute leaves. Score sheet was given so that their honest evaluation of the product can be solicited. The products were evaluated as to aroma, color, texture taste and general acceptability. The score sheet will be gathered after the evaluation.

\section{Data Gathering Technique}

After the sensory evaluation of the finished products, responses of the evaluators were collected by the researcher. The evaluation scoresheet based on the five-point Hedonic Scale (Gatchalian, 1989) was modified by the researcher. The data was recorded, tallied, summarized and prepared for computation. 
Acceptability of the products as to appearance, aroma, taste, texture and general acceptability was analyzed and interpreted using the mean and standard deviation and One-Way Analysis of Variance was used to determine the significant difference at 0.01 level of significance.

The computed mean was analyzed and interpreted using the Arbitrary Scale:

4.21 to 5.0 Extremely liked, 3.41 to 4.20 Very much liked, 2.60 to 3.40 Moderately liked, 1.81 to2.60 Very much disliked, and 1.00 to 1.80 Extremely disliked.

Sensory evaluation score sheet based on the Five Point Hedonic Scale was used in determining the level of acceptability of the soursop tart filling enriched with $5 \mathrm{~g}, 10 \mathrm{~g}, 15 \mathrm{~g}$ jute leaves as to appearance, aroma, taste, texture and general acceptability.

Ingredients in Making Soursop Tart Filling with Jute Leaves

In conducting the experimental study, the following ingredients was used in the preparation of soursop tart filling with jute leaves: ripe soursop fruit, sugar and $5 \mathrm{~g}, 10 \mathrm{~g}, 15 \mathrm{~g}$ jute leaves .

Table 1: Distribution of Respondents

\begin{tabular}{lll}
\hline Categories & F & Percentage (\%) \\
\hline Entire Group & 72 & 100 \\
Students & 60 & 83 \\
Teachers & 12 & 17 \\
\hline
\end{tabular}

\section{Findings}

Table 2

Students' Responses on the Level of Acceptability of Soursop Tart Filling on A, B and C as evaluated on Appearance, Aroma, Taste. Texture and General Acceptability

\begin{tabular}{|c|c|c|c|c|c|c|c|c|c|}
\hline Criteria & & & A & & & & & & \\
\hline & $\mathrm{M}$ & SD & Description & $\mathrm{M}$ & SD & Description & $\mathrm{M}$ & SD & Description \\
\hline Appearance & 4.18 & .59 & $\begin{array}{l}\text { Very much } \\
\quad \text { liked }\end{array}$ & 4.41 & .49 & $\begin{array}{l}\text { Extremely } \\
\text { liked }\end{array}$ & 4.18 & .59 & $\begin{array}{l}\text { Very much } \\
\text { liked }\end{array}$ \\
\hline Aroma & 4.41 & .49 & Extremely liked & 4.21 & .80 & $\begin{array}{l}\text { Extremely } \\
\quad \text { liked }\end{array}$ & 2.9 & .10 & $\begin{array}{l}\text { Very much } \\
\text { liked }\end{array}$ \\
\hline Taste & 4.41 & .69 & Extremely liked & 3.85 & .75 & $\begin{array}{l}\text { Very much } \\
\quad \text { liked }\end{array}$ & 4.30 & .64 & $\begin{array}{l}\text { Extremely } \\
\quad \text { liked }\end{array}$ \\
\hline Texture & 3.86 & .70 & $\begin{array}{l}\text { Very much } \\
\quad \text { liked }\end{array}$ & 3.96 & .82 & $\begin{array}{l}\text { Very much } \\
\quad \text { liked }\end{array}$ & 3.76 & .78 & $\begin{array}{l}\text { Very much } \\
\quad \text { liked }\end{array}$ \\
\hline $\begin{array}{l}\text { General } \\
\text { Acceptability }\end{array}$ & 3.75 & .67 & $\begin{array}{l}\text { Very much } \\
\text { liked }\end{array}$ & 4.53 & .67 & $\begin{array}{c}\text { Extremely } \\
\text { liked }\end{array}$ & 4.45 & .50 & $\begin{array}{l}\text { Extremely } \\
\text { liked }\end{array}$ \\
\hline
\end{tabular}

Legend: $A=$ Soursop Tart Filling with 5 g. jute leaves

$B=$ Soursop Tart Filling with $10 \mathrm{~g}$. jute leaves

$C=$ Soursop Tart Filling with $15 \mathrm{~g}$. jute leaves 
Table 3

Teachers' Responses on the Level of Acceptability of Soursop Tart Filling on A, B and C as evaluated on Appearance, Aroma, Taste. Texture, General Acceptability

\begin{tabular}{|c|c|c|c|c|c|c|c|c|c|}
\hline Criteria & $\mathrm{A}$ & & & $\mathrm{B}$ & & & $\mathrm{C}$ & & \\
\hline & $\mathrm{M}$ & SD & Description & $\mathrm{M}$ & SD & Description & $\mathrm{M}$ & SD & Description \\
\hline Appearance & 4.50 & .67 & $\begin{array}{l}\text { Extremely } \\
\text { liked }\end{array}$ & 3.50 & .52 & $\begin{array}{l}\text { Very much } \\
\text { liked }\end{array}$ & 4.50 & .67 & $\begin{array}{l}\text { Extremely } \\
\text { liked }\end{array}$ \\
\hline Aroma & 3.50 & .52 & $\begin{array}{l}\text { Very much } \\
\text { liked }\end{array}$ & 3.50 & .52 & $\begin{array}{l}\text { Very much } \\
\text { liked }\end{array}$ & 2.0 & .00 & $\begin{array}{l}\text { Very much } \\
\text { Disliked }\end{array}$ \\
\hline Taste & 4.00 & .000 & $\begin{array}{l}\text { Very much } \\
\text { liked }\end{array}$ & 4.50 & .67 & $\begin{array}{l}\text { Extremely } \\
\text { liked }\end{array}$ & 3.50 & .52 & $\begin{array}{l}\text { Very much } \\
\text { liked }\end{array}$ \\
\hline Texture & 4.50 & .67 & $\begin{array}{l}\text { Extremely } \\
\text { liked }\end{array}$ & 3.50 & .52 & $\begin{array}{l}\text { Very much } \\
\text { liked }\end{array}$ & 4.0 & .00 & $\begin{array}{l}\text { Very much } \\
\text { liked }\end{array}$ \\
\hline $\begin{array}{l}\text { General } \\
\text { Acceptability }\end{array}$ & 4.33 & .49 & $\begin{array}{l}\text { Extremely } \\
\text { liked }\end{array}$ & 4.0 & .00 & $\begin{array}{l}\text { Very much } \\
\text { liked }\end{array}$ & 4.41 & .51 & $\begin{array}{l}\text { Very much } \\
\text { liked }\end{array}$ \\
\hline
\end{tabular}

Table 4

One-Way ANOVA result on Responses of Respondents on the Level of Acceptability of Soursop Tart Filling on A, B and C as evaluated on Appearance, Aroma, Taste. Texture, General Acceptability

\begin{tabular}{lllllll}
\hline Source of Variation & $\begin{array}{l}\text { Sum of } \\
\text { Squares }\end{array}$ & $\begin{array}{l}\text { Mean } \\
\text { Square }\end{array}$ & F & Sig & $\begin{array}{l}\text { Statistical } \\
\text { Decision }\end{array}$ \\
\hline Between groups & .001 & 1 & .001 & .009 & .924 & Not Significant \\
Within groups & 7.687 & 70 & .110 & & & \\
Total & 7.688 & 71 & & & & \\
\hline
\end{tabular}

$\mathrm{P}>.01$

\section{Discussion}

When the student respondents evaluated treatments A (5g jute) and $\mathrm{C}$ ( $15 \mathrm{~g}$ jute) in the tart fillings as to appearance it showed that they very much liked it, while on treatment B (10g jute) in the tart fillings it showed that they extremely liked it.

In contrast with the result of teacher-respondents evaluation, it showed that they extremely liked treatments $\mathrm{A}$ and $\mathrm{C}$ while very much liked treatment $\mathrm{B}$.

This result was supported by Dadivas (2008) who conducted a study on the acceptability of mangotart filling in different proportions in terms of appearance, aroma, flavor and texture of mango-tomato tart filling in different proportions. The study revealed that the respondents "liked very much" and acceptable in terms of appearance, aroma, flavor and texture.

When the students were asked to evaluate the product on treatment A, B in terms of aroma they extremely liked it, while they very much liked treatment $\mathrm{C}$. However, teachers very much disliked treatment $\mathrm{C}$ and very much liked treatment $\mathrm{A}$ and $\mathrm{B}$.

This is in contrast with the result of the study of Hontanar (2002, ) in the study of fries out of Palawan (Crystospera mukush) determined the acceptability of fries out of Palawan using direct and halfcooked method in terms of appearance, aroma, flavor, texture and general acceptability. The products were evaluated by three groups of evaluators composed of teachers, parents and students. Based on the findings of the study, Palawan half-cooked method was liked very much in terms of appearance, aroma, flavor, texture and general acceptability. 
In the present study, the aroma of soursop tart filling enriched with jute leaves has a very pleasant odor. This implies that the smell of soursop, tart and jute leaves plays an important factor in the acceptability of the product. According to De Leon (1999) specific foods is associated with specific odor.

As to taste, treatment A, C was extremely liked and treatment B was very much liked by the student evaluators while the teachers rated the product on treatment A, C as "very much liked" and B as "extremely liked".

This findings was almost similar to the result of the study of Depra (2011) on butterscotch cookies enriched with powdered malunggay leaves revealed that the taste of butterscotch cookies enriched with powdered malunggay leaves were liked extremely by the respondents because the flavor was pleasing, the ingredients were blended and off taste of powdered malunggay. This implied that the powdered malunggay leaves and powdered jute leaves were added to the tart as they do not give unpleasant taste.

When the student evaluators rated the treatment A,B,C in terms of texture they liked it very much. The teachers extremely liked the treatment A and very much like treatment B and C.

Closely similar result was of Apistar (2014) on the study on sugar cookies enriched with powdered jute leaves. Findings revealed that treatment A, B, C, and D were extremely liked by the respondents. This means that sugar cookies enriched with powdered jute leaves in different measures were extremely liked by the panel of evaluators. This implies that regardless of the amount of powdered jute leaves added to sugar cookies the texture of the product was all acceptable to the evaluators.

When the student respondents evaluated treatments $\mathrm{B}$ and $\mathrm{C}$ in the tart fillings as to general acceptability it showed that they extremely liked it, while on treatment $\mathrm{A}$ in the tart fillings it showed that they very much liked it.

In contrast with the result of teacher-respondents evaluation, it showed that they extremely liked treatments A while very much liked treatment B and C.

Another similar result of findings of Apistar (2014) on sugar cookies enriched with powdered jute leaves revealed that sugar cookies with powdered jute leaves were the most acceptable since they were extremely liked by the group of evaluators as to its general acceptability and very comparable in all sensory characteristics.

\section{Conclusion}

Based on the foregoing findings the following conclusions and recommendations:

1. Regardless of treatment done the soursop tart filling with jute leaves is very much liked by students and teachers in terms appearance, aroma, taste, texture and general acceptability

2. Students and teachers liked very much the soursop tart filling when enriched with the fresh jute leaves, thus , will provide them nutritious and healthy food to eat;

3. Fruit filling gave top quality products but it requires a lot of labor and is dependent on season;

\section{Recommendations}

1. Since soursop tart filling with jute leaves is generally acceptable to students and teachers it's preparation is encouraged for family consumption, means of livelihood to augment income and an income generating project of the school.

2. Production and Extension are two of the mandated functions of the university system, thus, the administration must support the dissemination and launching of product through extension lectures and trainings.

3. The community especially in the field of agriculture must support the plantation of soursop since it is a potential for product enrichment aside from tart fillings, thus, future may utilize the result of this study to fill in the gaps of knowledge that this study left 


\section{References}

Al-Amonde,W.(2012). Protective effect of Vitamin C against canbonfuram-induced testicular toxicity in albine mice.

Apistar, V (2014). Sugar Cookies enriched with powdered jute ( Corchurus Olitorious) leaves. ). Unpublished Master's Thesis. WVCST, La Paz, Iloilo City

Biton,Alejo.(2009) Conduction and Reporting Research. Methodology of Research I. University of San Agustin, Iloilo City, Philippines.

Dadivas, Lorina B. (2008). Mango (Mangifera Indica) Tomato (Lycopersicum Esculentum) Tart filling. WVCST. Iloilo City

De Leon, Et. Al (1999). Basic Foods for Filipino. Merriam and Webster bookstore Inc.

Depra R.V. (2011). Butterscotch cookies enriched with malunggay (Moringa Oleifera) leaves ). Unpublished Master's Thesis. WVCST, La Paz, Iloilo City

Gatchalian, M.(1989).Sensory Evaluation Method.Quezon City, College of Home Economics. U.P. Diliman

Hontanar,V. (2002). Fries Out of Palawan ( Crystosperma Merkush). Unpublished Master's

Thesis.

WVCST, La Paz, Iloilo City 


\section{West Visayas State University}

Janiuay Campus

Janiuay, Iloilo

"SOURSOP (ANNONA MURICATA) TART FILLING WITH JUTE (CORCHORUS

OLITORIOUS) LEAVES"

\section{Personal Information}

Name: (Optional)

Student

Faculty

\section{Modified Sensory Evaluation Score Sheet}

\begin{tabular}{|c|c|c|c|c|c|}
\hline Criteria & $\begin{array}{c}5 \\
\text { Extremely } \\
\text { liked }\end{array}$ & $\begin{array}{c}4 \\
\text { Very much } \\
\text { liked }\end{array}$ & $\begin{array}{c}3 \text { Moderately } \\
\text { liked }\end{array}$ & $\begin{array}{c}2 \\
\text { Very much } \\
\text { disliked }\end{array}$ & $\begin{array}{c}1 \\
\text { Extremely } \\
\text { Disliked }\end{array}$ \\
\hline Appearance & $\begin{array}{l}\text { Extremely } \\
\text { creamy and } \\
\text { appealing in } \\
\text { color; shiny } \\
\text { appearance }\end{array}$ & $\begin{array}{l}\text { Very much } \\
\text { creamy and } \\
\text { appealing in } \\
\text { color; shiny } \\
\text { appearance }\end{array}$ & $\begin{array}{l}\text { Moderately } \\
\text { creamy and } \\
\text { appealing in } \\
\text { color; shiny } \\
\text { appearance }\end{array}$ & $\begin{array}{l}\text { Very much } \\
\text { disliked } \\
\text { darker color } \\
\text { and dull } \\
\text { appearance }\end{array}$ & $\begin{array}{l}\text { Extremely } \\
\text { disliked } \\
\text { darker color } \\
\text { and dull } \\
\text { appearance }\end{array}$ \\
\hline Aroma & $\begin{array}{l}\text { Extremely } \\
\text { pleasant and } \\
\text { stimulating } \\
\text { soursop with } \\
\text { jute aroma }\end{array}$ & $\begin{array}{l}\text { Very much } \\
\text { pleasant and } \\
\text { stimulating } \\
\text { soursop with } \\
\text { jute aroma }\end{array}$ & $\begin{array}{l}\text { Moderately } \\
\text { pleasant and } \\
\text { stimulating } \\
\text { soursop with } \\
\text { jute aroma }\end{array}$ & $\begin{array}{l}\text { Very much } \\
\text { unpleasant } \\
\text { smell }\end{array}$ & $\begin{array}{l}\text { Extremely } \\
\text { unpleasant } \\
\text { smell. }\end{array}$ \\
\hline Taste & $\begin{array}{l}\text { Extremely } \\
\text { sweet and } \\
\text { savory; } \\
\text { pleasing } \\
\text { soursop with } \\
\text { jute flavor }\end{array}$ & $\begin{array}{l}\text { Very sweet and } \\
\text { savory; } \\
\text { pleasing } \\
\text { soursop with } \\
\text { jute flavor }\end{array}$ & $\begin{array}{l}\text { Moderately } \\
\text { sweet and } \\
\text { savory; } \\
\text { pleasing } \\
\text { soursop with } \\
\text { jute flavor }\end{array}$ & $\begin{array}{l}\text { Very sour and } \\
\text { distasteful } \\
\text { soursop with } \\
\text { jute flavor }\end{array}$ & $\begin{array}{l}\text { Extremely } \\
\text { sour and } \\
\text { distasteful } \\
\text { soursop with } \\
\text { jute flavor }\end{array}$ \\
\hline Texture & $\begin{array}{l}\text { Extremely fine } \\
\text { soursop with } \\
\text { jute }\end{array}$ & $\begin{array}{l}\text { Very fine } \\
\text { soursop with } \\
\text { jute }\end{array}$ & $\begin{array}{l}\text { Moderately } \\
\text { fine soursop } \\
\text { with jute }\end{array}$ & $\begin{array}{l}\text { Very coarse } \\
\text { soursop with } \\
\text { jute }\end{array}$ & $\begin{array}{l}\text { Extremely } \\
\text { coarse } \\
\text { soursop with } \\
\text { jute }\end{array}$ \\
\hline $\begin{array}{l}\text { General } \\
\text { Acceptability }\end{array}$ & $\begin{array}{l}\text { Product is } \\
\text { extremely } \\
\text { acceptable }\end{array}$ & $\begin{array}{l}\text { Product is very } \\
\text { much } \\
\text { acceptable }\end{array}$ & $\begin{array}{l}\text { Product is } \\
\text { moderately } \\
\text { acceptable }\end{array}$ & $\begin{array}{l}\text { Product is } \\
\text { very much } \\
\text { unacceptable }\end{array}$ & $\begin{array}{l}\text { Product is } \\
\text { extremely } \\
\text { unacceptable }\end{array}$ \\
\hline
\end{tabular}

